\title{
Rational and behavioural predictors of pre-retirement cash-outs
}

\author{
Michelle Reyers ${ }^{\mathrm{a} *}$ \\ Cornelis Hendrik Van Schalkwyk ${ }^{\mathrm{a}}$ \\ Daniël Gerhardus Gouws ${ }^{\mathrm{a}}$ \\ ${ }^{\mathrm{a} D e p a r t m e n t ~ o f ~ F i n a n c i a l ~ M a n a g e m e n t, ~ U n i v e r s i t y ~ o f ~ P r e t o r i a ~}$ \\ Private Bag X20, Hatfield, Pretoria, 0028, Republic of South Africa \\ *Corresponding author: michelle.reyers@up.ac.za
}

This manuscript has been accepted for publication in Journal of Economic Psychology. The manuscript will undergo copyediting, typesetting, and review of the resulting proof before it is published in its final form. Please note that during the production process errors may be discovered which could affect the content, and all disclaimers that apply to the journal apply to this manuscript. A definitive version was subsequently published in Journal of Economic Psychology, [Vol 47, 2015] doi:10.1016/j.joep.2015.01.005

\begin{abstract}
Given the worldwide concern that individuals are not saving sufficiently for retirement, many governments are taking action to try and rectify this tendency. A key focus area is implementing policies to dissuade individuals from accessing accumulated retirement funds when changing jobs. While traditional economic theories assume that individuals act rationally and make optimal decisions without outside intervention, current policy interventions support behavioural theories of decision-making where sub-optimal choices occur due to limitations in human decision-making. Therefore, interventions are based on the assumption that individuals act irrationally. Despite these interventions, many individuals still
\end{abstract}


access their funds suggesting that current interventions may not be sufficiently aligned with the factors influencing decision making in this environment.

The main research objective of this study was to test empirically both rational and behavioural factors that could potentially influence retirement preservation decisions, to determine which factors were the best predictors of whether an individual preserved funds when changing jobs. A research instrument was designed using a combination of existing psychometric measures and customised questions to form an analytical survey. This was used to test the factors that predicted the preservation decisions of a sample of 256 academic and non-academic personnel at a tertiary education institution in South Africa.

The study found that behavioural factors play an important role in predicting preservation decisions. In particular, behavioural factors related to bounded rationality, due to the computational complexity of the decision-making environment, emerged as important explanatory variables, indicating that interventions such as decision support and guidance may assist individuals in making optimal decisions.

Keywords: pre-retirement cash outs; life-cycle hypothesis; behavioral life-cycle hypothesis; bounded willpower; bounded rationality

\section{Introduction}

Should policy makers intervene in individual retirement decision-making, and if so, what form should such intervention take? From hard-line paternalistic interventions to more liberal "nudges", the debate is on-going as to the role government should play in ensuring that individuals retire with sufficient savings. Given the worldwide concern that individuals are not saving sufficiently for retirement, many governments are taking action to reverse this trend. A key focus area is dissuading individuals from accessing accumulated retirement funds when changing jobs, as the problem of low levels of preservation is increasingly 
recognised as a crucial issue that may result in insufficient savings at retirement (South Africa, National Treasury, 2007; United States, Working Group on Retirement Plan Leakage, 1998).

In light of these concerns, governments have attempted to decrease withdrawals through policy intervention (John \& Iwry, 2008; South Africa, National Treasury, 2013). In a number of countries, such as Australia, Canada and the United Kingdom, pension withdrawals are strictly regulated and in most cases pre-retirement withdrawals are prohibited, while in other countries, such as the United States, pension withdrawals prior to retirement are discouraged through the use of taxes and penalties (Bassett, Fleming, \& Rodrigues, 1998; South Africa, National Treasury, 2012). In South Africa taxes are used to discourage withdrawals. The system is based on cumulative withdrawals, providing for an initial tax free amount of $\mathrm{R} 22,500$ and a sliding scale of taxes for withdrawals above this amount ranging from $18 \%$ to 36\% (Stiglingh, Koekemoer, van Schalkwyk, Wilcocks, \& de Swardt, 2013). As part of a broader retirement reform process, the South African government's aim is to introduce mandatory preservation, however the proposal is still under discussion and an implementation date has not yet been finalised (South Africa, National Treasury, 2014).

While traditional economic theories assume that individuals act rationally and make optimal decisions without outside intervention, the policies initiated by various governments appear to contradict these traditional theories in that they assume that intervention is required. This approach is more in line with behavioural theories of decision-making, which assume that limitations in human decision-making can lead to sub-optimal choices. Therefore, the policies are put in place based on the assumption that individuals act irrationally and will, if left to their own devices, take a cash payout as they do not have the requisite self-control needed to 
save for retirement. However the current interventions which use tax penalties do not appear to be effective for the majority of those who face cash-out decisions. Studies in the United States have found that between one half and two-thirds of employees take a cash payout of accumulated retirement funds when moving jobs (Bassett et al., 1998; Engelhardt, 2002; Munnell, Golub-Sass, \& Muldoon, 2009). Research in South Africa has also found that the majority of individuals do not preserve retirement funds when switching employers, instead they choose to take a cash payment (Sanlam Employee Benefits, 2013; South Africa, National Treasury, 2007).

In theory, the reasons for choosing to take a cash payout rather than preserving retirement funds when leaving a job could be driven by either rational or irrational factors. Rational reasons would focus on the predictions of the life-cycle hypothesis (LCH) linked to consumption smoothing and liquidity constraints (Amromin \& Smith, 2003; Love, 2007), while irrational reasons could be driven by behavioural factors such as bounded willpower linked to self-control problems or bounded rationality stemming from the computational complexity of the decision-making environment (Desai, 2011; Jolls, Sunstein, \& Thaler, 1998; Monahan, 2004; Thaler, 1994) and would therefore be more in line with the behavioural life-cycle hypothesis (BLCH) (Shefrin \& Thaler, 1988).

While a number of theoretical papers have been written about the potential influence of behavioural factors on decision-making both in the accumulation and decumulation phases of retirement (Benartzi, Previtero, \& Thaler, 2011; Monahan, 2004; Thaler, 1994), to date, empirical studies of retirement savings decisions have generally focussed on testing these theories in the context of enrolment decisions, contribution rates and asset allocation decisions (Benartzi \& Thaler, 2007). None to our knowledge comprehensively test the 
influence of behavioural factors in the context of retirement preservation decisions. Existing empirical tests of factors that influence preservation decisions have focussed almost exclusively on demographic and socioeconomic variables to explain preservation decisions (Amromin \& Smith, 2003; Bassett et al., 1998; Engelhardt, 2003; Hurd \& Panis, 2006; Moore \& Muller, 2002; Munnell et al., 2009; Poterba, Venti, \& Wise, 1998), with some information related to education levels and financial planning horizons providing superficial insights into behavioural aspects. These studies do not, however, explicitly consider the role played by behavioural factors. This omission is perhaps due to the difficulty in obtaining information about behavioural constructs such as bounded willpower and bounded rationality in the existing surveys and data sets which have been used for these analyses.

Therefore, the problem that emerges is that there is a lack of understanding of all the factors which play a role in retirement preservation decisions. The current regulatory interventions in retirement preservation decisions assume irrationality in the decision-making process. However, despite the presence of taxes, high cash-out levels are still observed, suggesting that current interventions may not be aligned with the underlying factors that drive decisions. By assessing which factors predict whether an individual preserves funds when moving jobs, greater insight may be obtained regarding more appropriate interventions.

The main research objective of this study was to test empirically both rational and behavioural factors that could potentially influence retirement preservation decisions in order to determine which factors were the best predictors of whether an individual preserved funds when changing jobs. The contribution that this study consequently makes is both in the design of a research instrument that explicitly accounts for behavioural factors in retirement 
preservation decisions and the subsequent empirical testing of this instrument to ascertain the importance of behavioural factors in these decisions.

The first part of this paper outlines why there is a renewed focus on the rationality of the individual decision-maker. The factors that potentially play a role in retirement preservation decisions are highlighted and the implications for interventions are discussed in the context of a conceptual model. Thereafter the method selected to test the conceptual model empirically is explained. The final part of the paper contains the results and a discussion of the theoretical and practical implications of the research.

\section{Theoretical framework}

One of the key international trends in the retirement industry over the past few decades has been the move from a defined benefit to a defined contribution approach to retirement saving. This move has seen increased responsibility being placed on the individual in terms of choices and decisions that need to be made (Monahan, 2004). Any weaknesses in the decision-making process of the individual could have a negative impact on the ability of the individual to retire with sufficient funds. There has consequently been a renewed focus on the decision-making process of the individual, with the aim of determining whether it is as rational as traditional economic theory assumes, or whether behavioural factors, such as computational limitations, and self-control issues, play a role.

As outlined in section 1, the reasons for choosing to take a cash payout rather than preserving retirement funds when leaving a job can be either rational or irrational. While rational factors would focus on factors linked to the $\mathrm{LCH}$ such as age and financial circumstances, the main behavioural factors which have the ability to influence retirement decisions can be broadly 
categorised as bounded rationality and bounded willpower (Desai, 2011; Jolls et al., 1998; Thaler \& Sunstein, 2008).

Bounded rationality generally refers to cognitive limitations of the decision-maker resulting from limited computational capacity and knowledge (Simon, 1987). Therefore it would be expected that those who are more knowledgeable and have the ability to carry out the necessary computations would be less likely to make sub-optimal decisions. In general, however, savings decisions are complex, and many individuals may not have the requisite knowledge or computational ability. Usually when confronted by difficult computations, the human brain makes use of heuristics, or mental shortcuts, to solve problems, however, this process is only useful if there are good heuristics to apply, which is generally not the case in the context of retirement savings decisions (Thaler, 1994). In the absence of useful heuristics, individuals can try to establish what to do by learning from others. This may include following the advice of individuals perceived as knowledgeable experts or mimicking the actions of peers (Benartzi \& Thaler, 2007). Alternatively individuals may regard external cues, such as defaults, as advice regarding the correct course of action to take (Madrian \& Shea, 2001).

Bounded willpower is linked to self-control and procrastination which result from situational and temporal inconsistencies (Monahan, 2004). These inconsistencies are generally associated with an individual's level of impulsivity and time perspective. Time perspective reveals how an individual relates to the past, present and future (Boniwell \& Zimbardo, 2004) while impulsivity is linked to low levels of self-control and the inability to delay gratification (Evenden, 1999). Being able to exert impulse control and a future-oriented time perspective 
are believed to play an important part in increasing self-control (Loewenstein, 1996) and overcoming procrastination (Ferrari \& Díaz-Morales, 2007).

Whether individuals are seen to be acting rationally or irrationally in their decision-making process will ultimately determine if intervention is necessary and there are a variety of approaches in this regard (Desai, 2011). At one end of the spectrum a pure libertarian approach is followed where no intervention is required as it is assumed that individuals act rationally. At the opposite end a purely paternalistic policy is followed where regulatory intervention dictates how individuals should behave, based on the assumption that individuals act irrationally. A middle ground is occupied by libertarian paternalism, which combines libertarian and paternalistic aspects to assist individuals in making optimal choices (Sunstein \& Thaler, 2003). This can be achieved through the use of behavioural tools such as choice architecture in the design of products, policies and so forth (Thaler, Sunstein, \& Balz, 2010). Alternatively education and debiasing may assist individuals to overcome specific biases in the decision-making process (Larrick, 2004). Generally regulatory interventions, and in some instances choice architecture, would benefit those with bounded willpower, whereas education and debiasing would assist in the case of bounded rationality (Desai, 2011).

The factors which potentially explain preservation decisions, and the implications for interventions, can be explained in the context of a conceptual model. The model outlines that the factors which explain preservation decisions can be categorised into a rational model, a behavioural model based on limitations as a result of bounded rationality and a behavioural model based on limitations as a result of bounded willpower. Each model provides different predictions of the factors that potentially account for low levels of preservation, and in light 
of this, what interventions are required to ensure optimal preservation decisions and how the current system of tax penalties may influence these decisions.

In terms of the rational model, low levels of preservation would be driven by consumption smoothing and liquidity constraints. Therefore low levels of preservation would be expected among those who are young or liquidity constrained. In this instance, no intervention is required as individuals should be allowed to access funds to facilitate consumption smoothing or overcome situations in which they are liquidity constrained. However, in the presence of tax penalties, those acting rationally run the risk of being penalised as accessing funds for consumption smoothing could result in an additional tax burden. This impact might be mitigated by the fact that in some jurisdictions, such as South Africa, small amounts are not taxed and younger individuals, who would typically access funds in terms of the LCH, would be expected to have accumulated smaller retirement balances. For those who are liquidity constrained, studies have found that tax penalties are generally ineffective, as individuals are willing to incur the penalty to gain access to much needed cash (Chang, 1996). Therefore in the presence of taxes, low levels of preservation would be expected among those who are young, with access to smaller accumulated funds, and those who are liquidity constrained.

From the perspective of a behavioural model related to bounded rationality, it would be expected that those who are better educated or have higher levels of financial knowledge might be more capable of making optimal decisions. In this regard, studies have found positive relationships between financial knowledge and retirement planning and savings decisions (Klapper \& Panos, 2011; Lusardi \& Mitchell, 2011; van Rooij, Lusardi, \& Alessie, 2011). For individuals who are not able to overcome the computational complexity, interventions would be required to assist individuals in making optimal choices using 
decision guidance or support (Larrick, 2004). Given the current taxes levied on withdrawals, it would be expected that a knowledgeable individual, who understands the detrimental impact of taxes on withdrawals, and who has the ability to understand and apply the impact of compounding over a future time period, would generally preserve funds. It would also be expected, that a knowledgeable expert providing advice to an individual would in most cases advise preservation for the same reasons. However, those who are unable to overcome the computational complexity of the retirement preservation decision would be less likely to preserve funds as they would not necessarily understand the longer term implications of withdrawing funds, coupled with the adverse impact of taxes. Thus low levels of preservation would be expected among those who had low levels of education, low levels of financial literacy or those who did not seek advice regarding their decision.

The behavioural model linked to bounded willpower would predict that those with low levels of self-control would be less likely to preserve funds. Self-control has been found to play an important role in general savings behaviour (Rabinovich \& Webley, 2007) and more specifically in retirement savings behaviour (Hershey \& Mowen, 2000; Jacobs-Lawson \& Hershey, 2005; Monahan, 2004). Therefore, if an individual had a time orientation that focused on the present, or high levels of impulsivity, it would be expected that the individual would not preserve funds. The interventions in this case would generally be focussed on regulatory intervention, in the form of taxes or mandatory preservation. From the perspective of tax penalties, it has been suggested that to be effective as self control mechanisms, penalties of up to 50 percent might be optimal (Laibson, Repetto, \& Tobacman, 1998). Therefore, if the tax penalties that are in place are not a sufficient deterrent, those with low levels of self control would still be expected to access funds. 
While previous studies of preservation decisions have focused mainly on demographic and socioeconomic variables this provides only partial insight into what drives low preservation levels. A study which explicitly includes behavioural factors will provide much needed insight regarding the suitability of existing and proposed interventions. The objective of this study is, therefore, to test empirically multiple potential factors which play a role in preservation decisions, so as to provide a more comprehensive assessment of the main predictors of preservation.

\section{Methods}

\subsection{Research design and instrument}

The research design adopted for this study was an analytical survey which allowed the testing of the relationship between the factors identified in the conceptual model (predictor variables) and the decision to preserve funds when moving jobs (the outcome variable). The customised survey took the form of a structured questionnaire and used existing measures of predictor variables, where available, supplemented with additional questions to capture factors for which there are no existing measures. A copy of the research instrument is available from the corresponding author.

\subsubsection{Variables}

To collect the information for the outcome variable, questions were included to determine what action the individual took when they moved jobs with respect to their accumulated retirement funds. Then, using the conceptual model discussed in section 2, predictor variables to assess the potential causes of low levels of preservation were incorporated in the questionnaire. Table 1 provides a summary of these variables and what their theoretically predicted impact would be. 
Table 1: Potential factors which could drive low preservation levels and their related measures

\begin{tabular}{|c|c|c|c|}
\hline $\begin{array}{l}\text { Decision } \\
\text { frame }\end{array}$ & Potential causes & $\begin{array}{l}\text { Measure / Predictor } \\
\text { variable }\end{array}$ & $\begin{array}{l}\text { What would predict low levels of } \\
\text { preservation }\end{array}$ \\
\hline Rational & $\begin{array}{l}\text { Consumption } \\
\text { smoothing / } \\
\text { Necessity }\end{array}$ & $\begin{array}{l}\text { Age } \\
\text { Reason for leaving job } \\
\text { Salary } \\
\text { Net Asset Value (NAV) } \\
\text { Self-assessed financial } \\
\text { situation } \\
\text { Relationship status }\end{array}$ & $\begin{array}{l}\text { Young } \\
\text { Did not move to a better job } \\
\text { Low salary } \\
\text { Low NAV } \\
\text { Assess financial situation as poor } \\
\text { Divorced, separated, widowed }\end{array}$ \\
\hline $\begin{array}{l}\text { Bounded } \\
\text { rationality }\end{array}$ & $\begin{array}{l}\text { Computational } \\
\text { complexity }\end{array}$ & $\begin{array}{l}\text { Education level } \\
\text { Financial literacy test score } \\
\text { Professional advice }\end{array}$ & $\begin{array}{l}\text { Low levels of education } \\
\text { Low levels of financial literacy } \\
\text { Absence of professional advice }\end{array}$ \\
\hline \multirow[t]{2}{*}{$\begin{array}{l}\text { Bounded } \\
\text { willpower }\end{array}$} & $\begin{array}{l}\text { Limited self- } \\
\text { control }\end{array}$ & $\begin{array}{l}\text { Time perspective: } \\
\text { Consideration of Future } \\
\text { Consequences }(\mathrm{CFC}) \text { : CFC } \\
\text { immediate subscale and CFC } \\
\text { future subscale }\end{array}$ & $\begin{array}{l}\text { Low level of future orientation / } \\
\text { High level of present orientation }\end{array}$ \\
\hline & & $\begin{array}{l}\text { Level of impulsivity: Barratt } \\
\text { Impulsiveness Scale (BIS) }\end{array}$ & High levels of impulsivity \\
\hline Combination & Various & Amount of funds & Small amount \\
\hline
\end{tabular}


The variables related to the rational decision frame were informed by the socio-economic and demographic variables identified in previous studies of preservation referred to in section 1 . The specific measures for the behavioural decision frame are discussed in more detail below.

\subsubsection{Bounded rationality measures}

This study made use of the financial literacy index constructed by Lusardi and Mitchell (2009) with slight modifications to terminology to ensure suitability in a South African context. From a validity perspective, a strong correlation between subjective assessment of financial knowledge and the financial literacy index has been found (Lusardi \& Mitchell, 2009). This financial literacy index has been used, with slight variations, in other studies in a retirement context which find that financial literacy levels appear to be related to financial decision-making ability, making it a suitable measure for this present study (Bateman et al., 2011; Van Rooij, Lusardi, \& Alessie, 2012).

A question regarding highest level of educational qualification was included. In addition, questions were incorporated to determine whether individuals followed the advice of professional advisors (including financial advisors, human resources practitioners at the company and the administrators of retirement funds).

\subsubsection{Bounded willpower measures}

In order to measure the time orientation of the individual, the Consideration of Future Consequences (CFC) scale was used (Strathman, Gleicher, Boninger, \& Edwards, 1994). The CFC scale is one of the most commonly used measures of time perspective in psychological research (Hevey et al., 2010; Petrocelli, 2003). The scale has a high level of internal consistency and reliability (Finke, 2005; Hevey et al., 2010; Strathman et al., 1994). 
Numerous studies across a variety of domains have established construct validity of the CFC scale (for a review see Joireman, Strathman, \& Balliet, 2006).

This study made use of the newer 14-item scale with CFC-Immediate and CFC-Future subscales (Joireman, Shaffer, Balliet, \& Strathman, 2012). Exploratory and confirmatory factor analyses have established the validity of the scale, and high levels of reliability are observed (Joireman et al., 2012). In the present study, Cronbach's alpha scores indicated high levels of reliability for the CFC immediate subscale (0.817) and slightly lower, but still acceptable reliability for the CFC future subscale (0.730). A principal component analysis (PCA) of the fourteen items in the CFC scale was carried out and all items loaded on their expected scale.

The Barratt Impulsiveness Scale (BIS) (Patton, Stanford, \& Barratt, 1995) was selected as the measure for impulsivity. It is one of the best known and commonly administered measures of impulsivity (Stanford et al., 2009). The scale has high internal consistency and reliability, and construct validity has been established in the context of comparisons with other self-reported measures of impulsivity (Patton et al., 1995; Stanford et al., 2009). In the present study the BIS total scale showed high internal reliability with a Cronbach's alpha of 0.838 .

\subsubsection{Factors potentially attributable to both rational and behavioural influences}

Information regarding the amount of money available in the retirement fund at the time of a job move was also collected, as a number of studies have found that this is a potential predictor of preservation, with large balances more likely to be preserved (Bassett et al., 1998; Moore \& Muller, 2002; Munnell et al., 2009; Poterba et al., 1998). In the context of the conceptual model, the propensity to cash out small accumulated balances is difficult to categorise as an isolated factor as it could be rational or irrational. If low balances are 
indicative of low income levels or young employees, then cashing out these funds might result from liquidity constraints or consumption smoothing. However, a number of irrational factors might also result in the low levels of preservation of small balances as a result of mental accounting applied to "windfall income" (Shefrin \& Thaler, 1988), status quo bias as a result of default payouts of small balances (Choi, Laibson, Madrian, \& Metrick, 2004), or bounded rationality as tax penalties and default options provide external cues or are perceived as "advice" regarding the correct course of action to take (Madrian \& Shea, 2001). In a South African context there are no default payouts of small balances. However, small amounts can be withdrawn without paying taxes, and a sliding scale of taxes is applied to withdrawals. This tax structure might provide external cues to individuals that accessing smaller amounts is acceptable. In addition, from the perspective of bounded willpower, this sliding scale of taxes might result in individuals with limited self control being dissuaded from accessing funds only when the tax rate is high (i.e. on large amounts).

\subsection{Data collection}

\subsubsection{Sample}

The target population for this study was active retirement fund members in South Africa who had recently made a preservation decision when changing employers. A purposive sample was drawn from academic and non-academic staff members employed by a tertiary education institution in South Africa who had joined the staff in the past five years. There were 716 individuals included in the original sample. In the three-week data collection period, 526 individuals were located of whom 432 completed and returned the questionnaire, giving a response rate of $82 \%$ of those who were contacted and $60 \%$ of the total sample. Approximately one third of the questionnaires were completed by staff members who had not 
Table 2 Descriptive statistics of study variables

\begin{tabular}{|c|c|c|}
\hline Variable & $\begin{array}{l}\text { Frequency } \\
(\%)\end{array}$ & $\begin{array}{l}\text { Mean } \\
\text { (Standard deviation) }\end{array}$ \\
\hline \multicolumn{3}{|l|}{ Gender $(n=256)$} \\
\hline Male & 39.1 & \\
\hline Female & 60.9 & \\
\hline Age $(n=254)$ & & $36.8(8.4)$ \\
\hline \multicolumn{3}{|l|}{ Reason for job move $(n=255)$} \\
\hline Better job opportunity & 69.6 & \\
\hline Not a better job & 30.4 & \\
\hline \multicolumn{3}{|c|}{ Take home monthly salary $(n=246)$} \\
\hline Less than R10,000 & 7.3 & \\
\hline $\mathrm{R} 10,001-\mathrm{R} 20,000$ & 46.3 & \\
\hline $\mathrm{R} 20,001-\mathrm{R} 40,000^{\#}$ & 40.7 & \\
\hline More than R40,000 & 5.7 & \\
\hline \multicolumn{3}{|c|}{ Household Net Asset Value $(n=220)$} \\
\hline Less than R100,000" & 30.4 & \\
\hline $\mathrm{R} 100,001-\mathrm{R} 500,000$ & 19.6 & \\
\hline $\mathrm{R} 500,001-\mathrm{R} 1,000,000$ & 17.3 & \\
\hline More than R1,000,000 & 32.7 & \\
\hline \multicolumn{3}{|c|}{ Self assessed financial situation $(n=255)$} \\
\hline Very good & 9.4 & \\
\hline Good & 31.8 & \\
\hline Satisfactory & 49.0 & \\
\hline $\mathrm{Bad} /$ Very Bad ${ }^{\#}$ & 9.8 & \\
\hline \multicolumn{3}{|l|}{ Relationship status $(\mathrm{n}=\mathbf{2 5 6})$} \\
\hline Married/long term relationship & 72.3 & \\
\hline Single & 21.1 & \\
\hline Divorced/separated/widowed $^{\#}$ & 6.6 & \\
\hline
\end{tabular}




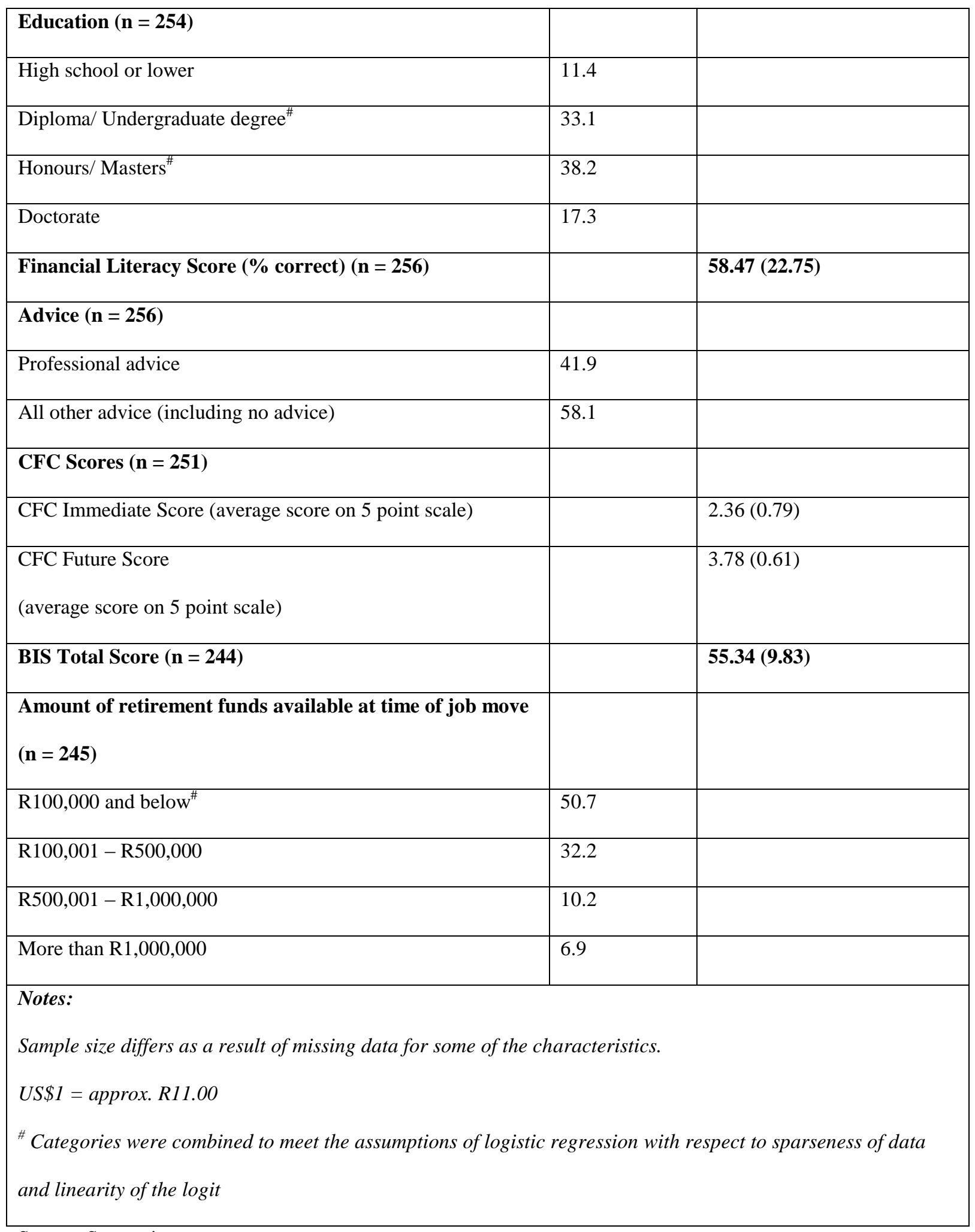

Source: Survey instrument

made a preservation decision, reducing the final sample for analysis to 256 . Table 2 contains descriptive statistics relating to the final sample. 
Data analysis

Binary logistic regression was used to analyse the data. Models were constructed using a purposeful selection model building approach (Hosmer \& Lemeshow, 2000; Hosmer, Lemeshow, \& Sturdivant, 2013). In terms of this approach, a bivariate analysis of all theoretically important variables was first carried out to determine statistical significance as standalone predictors. The Wald test statistic was used in the bivariate analysis to determine statistical significance.

Thereafter all variables found to be significant, using a cut-off $p$-value of 0.25 , were included in the multivariate model. This high p-value is recommended to ensure that suppressor effects are not missed where variables only become significant once other variables are introduced or controlled for (Hosmer et al., 2013). The significance of all variables was then reassessed in the combined model and those that were no longer significant were removed. However, following the recommendation of Agresti (1996), variables that are theoretically important were kept in the model to reduce bias in other estimates. In addition, the beta coefficients of variables remaining in the model were assessed to determine if major increases or decreases (in excess of 20\%) had occurred following the removal of non-significant variables, as this gives an indication that variables need to be added back as they act as effect moderators or controls (Hosmer \& Lemeshow, 2000; Hosmer et al., 2013). The statistical software package used for data analysis was IBM SPSS Statistics version 21.

\section{Research findings}

\subsection{The preservation decision}

Of the 256 respondents who made a preservation decision, $60 \%$ did not preserve their retirement funds and took the full amount in cash. Of those who preserved funds, 
approximately two-thirds transferred funds to a preservation fund, while one-third moved their funds to their new employer's pension or provident fund.

\subsection{Findings of bivariate analysis}

In general, according to the bivariate analysis of all variables included in the study and without controlling for the impact of other variables and interrelationships, almost all variables derived from the conceptual model were statistically significant predictors of whether an individual preserved or not $(\mathrm{p}<0.05)$. The relationship with preservation decisions was in line with what was theoretically predicted (refer to Table 1). Only the CFC future subscale $(\mathrm{p}=0.674)$ and relationship status $(\mathrm{p}=0.384)$ were not significant predictors of preservation decisions using the cut-off point of $\mathrm{p}<0.25$. The reason for leaving a job $(\mathrm{p}=0.061)$ was not significant at a $5 \%$ level but met the requirement for inclusion in the combined model based on the cut-off point of $\mathrm{p}<0.25$.

\subsection{Model building}

Once all the variables with statistically significant bivariate relationships were combined in the multivariate model, the following variables remained statistically significant predictors of preservation: education level; professional advice; the amount of funds; and reason for leaving the job. The use of backward stepwise regression confirmed the significance and inclusion of the above-mentioned predictor variables.

When comparing the smaller model with the one containing all variables, there were large changes in the beta coefficients of education and professional advice. The following variables were therefore added back: age, personal salary, self-assessed financial situation, BIS score, CFC immediate score and financial literacy score. This ensured that theoretically significant 
variables remained in the final model and that the resultant model showed acceptable levels of deviations in the beta coefficients of the four statistically significant variables (all changes were less than 20\%). No statistically significant interactions were found between variables.

In assessing the model adequacy and fit, Table 3 sets out the information regarding the specific details of the predictors included in the model, Table 4 provides information regarding overall model fit and Table 5 considers classification accuracy. The number of respondents included in this combined model was 217 , as a case-wise removal process was used for missing data on any of the variables.

The first four variables in Table 3 are the statistically significant predictors of preservation $(p<0.05)$, while the remaining variables are not significant predictors (beta coefficients are not statistically significantly different from zero) and are therefore assumed to have zero beta values in solving the logistic regression equation. However, as they are part of the overall model, the results are interpreted holding these variables constant.

The model was also run with the ordinal variables classified as categorical (i.e. using dummy variables) and the same four variables as highlighted in table 3, were found to be statistically significant predictors of preservation $(\mathrm{p}<0.05)$, while the remaining variables were not statistically significant predictors.

The generalised form of the logistic regression model is as follows: $\operatorname{logit}(\pi)=\ln (\pi /(1-\pi))=\alpha+\beta_{1} X_{1}+\beta_{2} X_{2}+\ldots \ldots+\beta_{p} X_{p}$ In general the interpretation of the above would be that for a given $\beta$ the natural logarithm of the odds of $Y=1$ increases by that $\beta$ value for a one unit increase in the predictor variable. 
Table 3: Significant predictors and control variables in combined model

\begin{tabular}{|c|c|c|c|}
\hline Variable & Beta coefficient (SE) & $\begin{array}{l}\text { Wald statistic: } \\
\text { significance }\end{array}$ & Odds Ratio \\
\hline Education level $\left(\mathrm{X}_{1}\right)$ & $\beta_{1:} 0.749(0.262)$ & $\mathrm{p}=0.004$ & 2.115 \\
\hline Professional advice $\left(\mathrm{X}_{2}\right)$ & $\beta_{2:} 1.172(0.362)$ & $\mathrm{p}=0.001$ & 3.227 \\
\hline Reason for leaving job $\left(\mathrm{X}_{3}\right)$ & $\beta_{3:} 0.975(0.404)$ & $\mathrm{p}=0.016$ & 2.650 \\
\hline Amount of funds $\left(\mathrm{X}_{4}\right)$ & $\beta_{4:} 0.710(0.278)$ & $\mathrm{p}=0.011$ & 2.034 \\
\hline Age at time of job move $\left(\mathrm{X}_{5}\right)$ & $\beta_{5:}-0.011(0.028)$ & $\mathrm{p}=0.685$ & 0.989 \\
\hline Self-assessed financial situation $\left(\mathrm{X}_{6}\right)$ & $\beta_{6:}-0.172(0.247)$ & $\mathrm{p}=0.485$ & 0.842 \\
\hline Personal salary $\left(\mathrm{X}_{7}\right)$ & $\beta_{7:} 0.190(0.334)$ & $\mathrm{p}=0.570$ & 1.209 \\
\hline CFC immediate subscale $\left(\mathrm{X}_{8}\right)$ & $\beta_{8:} 0.071(0.310)$ & $\mathrm{p}=0.819$ & 1.073 \\
\hline BIS score $\left(\mathrm{X}_{9}\right)$ & $\beta_{9:}-0.021(0.022)$ & $\mathrm{p}=0.357$ & 0.980 \\
\hline Financial literacy score $\left(\mathrm{X}_{10}\right)$ & $\beta_{10:} 0.063(0.203)$ & $\mathrm{p}=0.757$ & 1.065 \\
\hline Constant & $-3.669(1.615)$ & & \\
\hline
\end{tabular}

Source: SPSS output

The resultant logistic regression equation for this study is as follows (the specific variables are identified in Table 3):

$\ln (\pi /(1-\pi))=-3.669+0.749 X_{1}+1.172 X_{2}+0.975 X_{3}+0.710 X_{4}-0.011 X_{5}-0.172 X_{6}+0.190 X_{7}$

$+0.071 \mathrm{X}_{8}-0.021 \mathrm{X}_{9}+0.063 \mathrm{X}_{10}$

Therefore, if someone had a high school qualification, did not follow professional advice, did not leave for a better job and had accumulated retirement funds of less than R100,000 at the time of moving jobs, then the probability that that person preserved was $9.89 \%$. However, if someone held a doctorate, did follow professional advice, did leave for a better job and had 
accumulated retirement funds of more than $\mathrm{R} 1,000,000$ then the probability that that person preserved funds was $98.68 \%$.

To assess practical significance, in interpreting the odds ratio, holding all other variables constant:

- Each increase in level of education increased the odds of preserving by $111.5 \%$.

- Following professional advice increased the odds of preserving by $222.7 \%$, compared to someone who did not follow professional advice.

- If a person left for a better job, the odds of preserving increased by $165.0 \%$ compared to someone who did not leave for a better job.

- For each increase in the level of amount of funds available, the odds of preserving increased by $103.4 \%$.

The likelihood ratio test statistic in Table 4 shows that the overall model is statistically significantly different from a model with only the constant term. The Hosmer and Lemeshow test shows non-significance, indicating that the model fit is good (Hosmer \& Lemeshow, 2000). The McFadden $\mathrm{R}^{2}$ measure is within the range of 0.2 to 0.4 , which indicates a good level of fit (Hensher \& Johnson, 1981), and the Nagelkerke $\mathrm{R}^{2}$ is higher than this range. The area under the receiver operating characteristic (ROC) curve indicates that the model provides excellent discrimination between groups (Hosmer \& Lemeshow, 2000; Meyers, Gamst, \& Guarino, 2013). 
Table 4: Assessment of combined model fit

\begin{tabular}{|l|l|l|}
\hline Test & Value & Significance \\
\hline Likelihood Ratio test statistic & $82.531(\mathrm{df}=10)$ & $\mathrm{p}<0.001$ \\
\hline Hosmer and Lemeshow test & $6.920(\mathrm{df}=8)$ & $\mathrm{p}=0.545$ \\
\hline McFadden's R ${ }^{2}$ & 0.286 & \\
\hline Nagelkerke $\mathrm{R}^{2}$ & 0.430 & \\
\hline Area under the ROC curve & 0.833 & \\
\hline
\end{tabular}

Source: SPSS output

Table 5 highlights the fact that there are high levels of specificity in the model, while sensitivity is good; however, there are a number of false positives. In addition, the $78.8 \%$ predictive success rate of the model is $27.6 \%$ better than the base model and $49.3 \%$ better than the proportional by chance model, both of which are greater than the $25 \%$ that is generally expected of a good model (Hair, Black, Babin, \& Anderson, 2010).

Table 5: Classification table of combined model

\begin{tabular}{|c|c|c|c|}
\hline \multirow[b]{2}{*}{ Observed } & \multicolumn{3}{|l|}{ Predicted } \\
\hline & Did not preserve & Preserved & Percentage correct \\
\hline Did not preserve & 114 & 20 & 85.1 \\
\hline Preserved & 26 & 57 & 68.7 \\
\hline Overall Percentage & & & 78.8 \\
\hline
\end{tabular}

Source: SPSS output

\section{Discussion}

The objective of this study was to determine which factors predict whether an individual preserves funds when changing employers. Initial testing of all variables from the conceptual model on a standalone basis indicated that rational, bounded rational and bounded willpower 
factors all provided statistically significant predictions of preservation decisions. However, owing to the interrelatedness of a number of the variables, a combined model was constructed to determine which factors best predicted preservation, controlling for all other variables.

Only four variables remained statistically significant in the multivariate analysis: education level; reason for leaving job; professional advice; and the amount of funds. The overall model fit was very good, providing excellent levels of discrimination between those who preserved and did not preserve. Therefore, a model combining rational and behavioural factors identified that the most significant predictors of whether an individual preserved funds when changing employers were: moving to a better job; having a large amount of retirement funds available at the time of the job move; having a high education level; and following professional advice. The probability that such an individual preserved was close to $100 \%$, versus less than $10 \%$ for an individual at the opposite end of the spectrum.

These findings support some of the conclusions of previous research in this area which also found that the reason for a job move (Amromin \& Smith, 2003; Engelhardt, 2003; Hurd \& Panis, 2006), amount of funds available (Bassett et al., 1998; Moore \& Muller, 2002; Munnell et al., 2009; Poterba et al., 1998) and education level (Bassett et al., 1998; Hurd \& Panis, 2006; Poterba et al., 1998) are all factors that influence whether funds are preserved or not. While there does not appear to be much research regarding the use of professional advice and its impact on preservation decisions, this finding is confirmed by a recent South African industry survey which found strong associations between advice and preservation (Old Mutual, 2012). 
Although this study confirmed that age and financial situation were initial predictors of preservation, which was in line with the findings of many previous studies (Hurd \& Panis, 2006; Moore \& Muller, 2002; Poterba et al., 1998), these variables were not statistically significant in the context of a comprehensive model.

While previous studies had found that financial literacy is positively related to planning for retirement, this study only found statistical significance for this variable as a standalone predictor and not as part of the combined model. This could in part be due to the association between financial literacy and education as a number of studies have found strong relationships between these variables (see for example Van Rooij, Lusardi, \& Alessie, 2011). In this study, the scores on the financial literacy index were significantly correlated with education levels $\left(\mathrm{r}_{\mathrm{s}}=0.308, \mathrm{p}<0.001\right)$. The interrelationship between the variables might have resulted in the finding of non significance for financial literacy in the combined model.

When considering the impact of time orientation on the preservation decision, the CFC immediate subscale was a significant predictor of preservation on a standalone basis however the CFC future subscale was not. This appears to indicate that the relationship between time perspective and self-control arises due to a high concern with the immediate consequences of behavior rather than low concern with the future consequences of behavior, which supports the susceptibility hypothesis of the link between time orientation and self-control (Joireman et al., 2012). From the perspective of impulsivity, the BIS score was also found to be a statistically significant predictor as a standalone variable. This finding supports the view that level of impulsiveness plays a role in financial decision making (Ottaviani \& Vandone, 2011). However self-control linked to both time orientation and impulsivity were not statistically significant predictors of preservation in the combined model. The lack of 
explanatory power of these predictors in the combined model could be due to the deterrent effect of current taxes on withdrawals which might assist individuals in overcoming low levels of self control, particularly when the resultant tax rate is high. Alternatively, as individuals in this sample had all found a new job they may have some other characteristic that compensates for their impulsivity.

To correctly identify what interventions, if any, are required, the significant predictor variables were classified in the context of the conceptual model. Two of the predictors (professional advice and education level) form part of the bounded rationality model and appear to emphasise the role played by the inherent computational complexity of the preservation decision-making environment. However, education level is sometimes seen as a proxy for lifetime income (Van Rooij et al., 2012), and therefore this variable may also indicate that individuals with lower lifetime income access funds. The third predictor, which indicated whether an individual moved to a better job, highlights elements of consumption smoothing linked to the rational model of preservation. The impact was most pronounced for those earning low salaries where this appeared to be a key factor in deciding whether to preserve funds or not.

The last predictor variable was the amount of funds available at the time of job move. As discussed in section 3.1.1.3, the high propensity to cash out small amounts of funds could potentially arise from rational factors or behavioural factors such as bounded willpower related to self-control where low taxes on small amounts are not a sufficient deterrent, or as a result of mental accounting. Alternatively, bounded rationality as a result of the external cues created by tax incentives might also be a contributing factor. 
Therefore, although there is evidence of rational behaviour brought about by liquidity constraints, the predictors also highlight the prevalence of behavioural factors. While this study does not allow for conclusions to be drawn regarding causation, the key predictor variables do provide insight both in terms of who is most at risk of not preserving and, in light of this, what interventions might be appropriate.

It would appear that those who do not seek professional advice, those who have low retirement balances available at the time of moving jobs, those who have lower education levels and those not moving to a better job, are most at risk of not preserving funds. With respect to the latter category, there is a case to be made that these individuals should be allowed access to funds, particularly when they are unemployed. The need for such a concession is generally recognised by policy makers (Bassett et al., 1998; South Africa, National Treasury, 2013).

In terms of the practical significance of the findings, the role that professional advice played in predicting whether an individual preserved funds, suggests that providing advice to individuals at the time of moving jobs could be an important factor in assisting individuals to make optimal decisions. Given the uniqueness of each individual's financial situation, tailormade advice would be ideal but may be costly. However, the recent pension reforms in the United Kingdom, which also focus on the role that decision guidance can potentially play in the retirement environment, have outlined a way to provide free and impartial advice to retirees, by funding advice through a levy imposed on regulated financial services firms (HM Treasury, 2014). 
Suggestions for alternative interventions could include the use of decision tools and decision support systems (DSS). The intrinsic design of DSS potentially helps overcome bounded rationality in that it provides a mechanism for carrying out complex computations (Larrick, 2004). These tools may assist individuals in making optimal preservation decisions at the time of a job move, which aligns with the idea of just-in-time financial education (Fernandes, Lynch, \& Netemeyer, 2014). While the research in this area is limited, preliminary debiasing studies using DSS in investment and retirement decision making have produced positive results (Bhandari, Hassanein, \& Deaves, 2008; Looney \& Hardin, 2009). Whether the techniques can successfully be implemented in a retirement preservation decision making context has not been established. Therefore, there may be a need to consider alternative interventions, such as the more traditional approach of tax penalties to alter cash-out decisions to be closer to optimal. However, given the current high levels of cash outs where tax penalties are already in place, it would appear that higher penalties or mandatory preservation may be required. The drawback is that such interventions will penalise those who are liquidity constrained or participating in rational consumption smoothing and at the same time they will not address the underlying computational complexity of these decisions.

\section{Conclusions}

This study has highlighted the importance of behavioural factors in retirement preservation decisions. While current policy interventions are based on individuals displaying bounded willpower, the significance of education and professional advice in predicting preservation appear to support interventions related to bounded rationality resulting from the computational complexity of preservation decisions. Of key importance, from a practical perspective, is that following professional advice increased the odds that an individual preserved funds by $223 \%$ compared to someone who did not follow professional advice. 
Providing decision assistance when individuals move jobs may therefore be an effective solution to the problem of low preservation levels. The results of this study are therefore informative for policy makers, retirement fund providers and financial advisors.

This study contributes to the field of retirement finance and decision-making through the development of a survey instrument that explicitly tests behavioural factors in retirement preservation decisions, and initial testing of this instrument.

The design of the study and the nature of the sample may introduce some limitations. First from a design perspective there might be omitted variables that would more fully capture either rational or behavioural considerations. In addition, the lack of explanatory power of specific variables in the combined model might emerge from a mismeasurement of variables. However, care was taken in the selection of valid and reliable instruments for variables which may be more prone to mismeasurement, such as self control and financial literacy.

When considering the nature of the sample, the cross sectional explanatory power of predictor variables may not necessarily correspond to the importance of the predictor in driving cash-outs, particularly if there is very little variation in the predictor being measured in the sample. While this sample displayed heterogeneity across the study variables, in light of these potential limitations, further testing in other samples would be required before these results can be generalised.

Obtaining a clearer understanding of the limitations in the decision making process of individuals in a retirement context, and how to overcome these limitations, has widespread implications for future retirement stability and is an area that requires more research. This study has identified the potential role that decision guidance and support can play in assisting 
individuals to make optimal preservation decisions. Further exploring the impact of decision guidance and establishing the effectiveness of DSS in retirement preservation decisionmaking are areas for further research. In addition, given that increased job mobility has the potential to magnify the problem of low preservation of small amounts, further investigation of this phenomenon is required.

\section{References:}

Agresti, A. (1996). An introduction to categorical data analysis. New York: John Wiley. Amromin, G., \& Smith, P. (2003). What explains early withdrawals from retirement accounts? Evidence from a panel of taxpayers. National Tax Journal, 56(3), 595-612.

Bassett, W. F., Fleming, M. J., \& Rodrigues, A. P. (1998). How workers use 401(k) plans: the participation, contribution, and withdrawal decisions. National Tax Journal, 51(2), 263-289.

Bateman, H., Eckert, C., Geweke, J., Louviere, J., Thorp, S., \& Satchell, S. (2011). Financial competence and expectations formation: evidence from Australia. Economic Record, 88(280), 39-63.

Benartzi, S., Previtero, A., \& Thaler, R. H. (2011). Annuitization puzzles. Journal of Economic Perspectives, 25(4), 143-164.

Benartzi, S., \& Thaler, R. H. (2007). Heuristics and biases in retirement savings behavior. The Journal of Economic Perspectives, 21(3), 81-104.

Bhandari, G., Hassanein, K., \& Deaves, R. (2008). Debiasing investors with decision support systems: an experimental investigation. Decision Support Systems, 46(1), 399-410.

Boniwell, I., \& Zimbardo, P. G. (2004). Balancing time perspective in pursuit of optimal functioning. In P. A. Linley \& S. Joseph (Eds.), Positive psychology in practice (pp. 165-178). New Jersey: John Wiley. 
Chang, A. E. (1996). Tax policy, lump-sum pension distributions, and household saving. National Tax Journal, 49(2), 235-252.

Choi, J. J., Laibson, D. I., Madrian, B. C., \& Metrick, A. (2004). For better or for worse: default effects and 401(k) savings behavior. In D. A. Wise (Ed.), Perspectives on the economics of aging (pp. 81-126). Chicago: University Of Chicago Press.

Desai, A. C. (2011). Libertarian paternalism, externalities, and the "spirit of liberty": how Thaler and Sunstein are nudging us toward an "overlapping consensus." Law and Social Inquiry, 36(1), 263-295.

Engelhardt, G. V. (2002). Pre-retirement lump-sum pension distributions and retirement income security: evidence from the Health and Retirement Study. National Tax Journal, 55(4), 665-685.

Engelhardt, G. V. (2003). Reasons for job change and the disposition of pre-retirement lumpsum pension distributions. Economics Letters, 81(3), 333-339.

Evenden, J. L. (1999). Varieties of impulsivity. Psychopharmacology, 146(4), 348-361.

Fernandes, D., Lynch, J. G., \& Netemeyer, R. G. (2014). Financial literacy, financial education, and downstream financial behaviors. Management Science, 60(8), 18611883.

Ferrari, J. R., \& Díaz-Morales, J. F. (2007). Procrastination: different time orientations reflect different motives. Journal of Research in Personality, 41(3), 707-714.

Finke, M. S. (2005). Time orientation and economic decision making. In J. Joireman \& A. Strathman (Eds.), Understanding behavior in the context of time: theory, research and application (Kindle 2 version.). Retrieved from http://www.amazon.com

Hair, J. F., Black, W. C., Babin, B. J., \& Anderson, R. E. (2010). Multivariate data analysis: a global perspective (7th ed.). New Jersey: Pearson. 
Hensher, D. A., \& Johnson, L. W. (1981). Applied discrete-choice modelling. London: Taylor \& Francis.

Hershey, D. A., \& Mowen, J. C. (2000). Psychological determinants of financial preparedness for retirement. The Gerontologist, 40(6), $687-697$.

Hevey, D., Pertl, M., Thomas, K., Maher, L., Craig, A., \& Ni Chuinneagain, S. (2010). Consideration of Future Consequences scale: confirmatory factor analysis. Personality and Individual Differences, 48(5), 654-657.

HM Treasury. (2014). Millions guaranteed the right to free and impartial guidance on their new pensions choices. Retrieved from www.gov.uk

Hosmer, D. W., \& Lemeshow, S. (2000). Applied logistic regression (2nd ed.). New York: John Wiley.

Hosmer, D. W., Lemeshow, S., \& Sturdivant, R. X. (2013). Applied logistic regression (3rd ed.). New Jersey: John Wiley.

Hurd, M., \& Panis, C. (2006). The choice to cash out pension rights at job change or retirement. Journal of Public Economics, 90(12), 2213-2227.

Jacobs-Lawson, J. M., \& Hershey, D. A. (2005). Influence of future time perspective, financial knowledge, and financial risk tolerance on retirement saving behaviors. Financial Services Review, 14(4), 331-344.

John, D. C., \& Iwry, J. M. (2008). Protecting and strengthening retirement savings: strategies to reduce leakage in $401(k)$ s and expand savings through automatic IRAs: Special Committee on Aging, United States Senate. Retrieved from http://www.aging.senate.gov/events/hr198dj.pdf

Joireman, J., Shaffer, M. J., Balliet, D., \& Strathman, A. (2012). Promotion orientation explains why future-oriented people exercise and eat healthy: evidence from the two- 
factor Consideration of Future Consequences-14 scale. Personality and Social Psychology Bulletin, 20(5), 1-16.

Joireman, J., Strathman, A., \& Balliet, D. (2006). Considering future consequences: an integrative model. In L. Sanna \& E. Chang (Eds.), Judgments over time: the interplay of thoughts, feelings, and behavior. Oxford: Oxford University Press.

Jolls, C., Sunstein, C. R., \& Thaler, R. H. (1998). A behavioral approach to law and economics. Stanford Law Review, 50(5), 1471-1550.

Klapper, L., \& Panos, G. A. (2011). Financial literacy and retirement planning: the Russian case. Journal of Pension Economics and Finance, 10(04), 599-618.

Laibson, D. I., Repetto, A., \& Tobacman, J. (1998). Self-control and saving for retirement. Brookings Papers on Economic Activity, 1(1), 91-172.

Larrick, R. P. (2004). Debiasing. In D. J. Koehler \& N. Harvey (Eds.), Blackwell handbook of judgment \& decision making (pp. 316-338). Oxford: Blackwell.

Loewenstein, G. (1996). Out of control: visceral influences on behavior. Organizational Behavior and Human Decision Processes, 65(3), 272-292.

Looney, C. A., \& Hardin, A. M. (2009). Decision support for retirement portfolio management: overcoming myopic loss aversion via technology design. Management Science, 55(10), 1688-1703.

Love, D. A. (2007). What can the life-cycle model tell us about 401(k) contributions and participation? Journal of Pension Economics and Finance, 6(2), 147-185.

Lusardi, A., \& Mitchell, O. S. (2009). How ordinary consumers make complex economic decisions: financial literacy and retirement readiness. National Bureau of Economic Research Working Paper, 15350.

Lusardi, A., \& Mitchell, O. S. (2011). Financial literacy and retirement planning in the United States. Journal of Pension Economics and Finance, 10(04), 509-525. 
Madrian, B. C., \& Shea, D. F. (2001). The power of suggestion: inertia in 401 (k) participation and savings behavior. Quarterly Journal of Economics, 116(4), 11491187.

Meyers, L. S., Gamst, G., \& Guarino, A. J. (2013). Applied multivariate research: design and interpretation (2nd ed.). California: SAGE.

Monahan, A. B. (2004). Addressing the problem of impatients, impulsive and other imperfect actors in 401(k) plans. Virginia Tax Review, 23(3), 471-529.

Moore, J. H., \& Muller, L. A. (2002). An analysis of lump-sum pension distribution recipients. Monthly Labor Review, (May), 29-46.

Munnell, A. H., Golub-Sass, F., \& Muldoon, D. (2009). An update on 401(k) plans: insights from the 2007 SCF. Center for Retirement Research at Boston College. Retrieved from https://www2.bc.edu/ munnell/publications.shtml

Old Mutual. (2012). Old Mutual retirement monitor 2012. Retrieved from www.oldmutual.co.za

Ottaviani, C., \& Vandone, D. (2011). Impulsivity and household indebtedness: evidence from real life. Journal of Economic Psychology, 32(5), 754-761.

Patton, J. H., Stanford, M. S., \& Barratt, E. S. (1995). Factor structure of the Barratt Impulsiveness Scale. Journal of Clinical Psychology, 51(6), 768-774.

Petrocelli, J. V. (2003). Factor validation of the Consideration of Future Consequences scale: evidence for a shorter version. Journal of Social Psychology, 143(4), 405-413.

Poterba, J. M., Venti, S. F., \& Wise, D. A. (1998). Lump-sum distributions from retirement saving plans: receipt and utilization. In D. A. Wise (Ed.), Inquiries in the economics of aging (pp. 85-108). Chicago: University Of Chicago Press. 
Rabinovich, A., \& Webley, P. (2007). Filling the gap between planning and doing:

psychological factors involved in the successful implementation of saving intention. Journal of Economic Psychology, 28(4), 444-461.

Sanlam Employee Benefits. (2013). Sanlam Benchmark Survey 2013: member databook. Retrieved from http://www.sanlambenchmark.co.za

Shefrin, H. M., \& Thaler, R. H. (1988). The behavioral life-cycle hypothesis. Economic Inquiry, 26(4), 609-643.

Simon, H. A. (1987). Bounded rationality. In J. Eatwell, M. Murray, \& P. Newman (Eds.), The New Palgrave: a dictionary of economics (Vol. 1). London: The Macmillan Press.

South Africa, National Treasury. (2007). Social security and retirement reform: second discussion paper. Retrieved from www.treasury.gov.za

South Africa, National Treasury. (2012). Preservation, portability and governance for retirement funds. Retrieved from www.treasury.gov.za

South Africa, National Treasury. (2013). 2013 Retirement reform proposals for further consultation. Retrieved from www.treasury.gov.za

South Africa, National Treasury. (2014). 2014 Budget update on retirement reforms. Retrieved from www.treasury.gov.za

Stanford, M. S., Mathias, C. W., Dougherty, D. M., Lake, S. L., Anderson, N. E., \& Patton, J. H. (2009). Fifty years of the Barratt Impulsiveness Scale: an update and review. Personality and Individual Differences, 47(5), 385-395.

Stiglingh, M., Koekemoer, A. D., van Schalkwyk, L., Wilcocks, J. S., \& de Swardt, R. D. (2013). SILKE: South African income tax 2014. South Africa: LexisNexis. 
Strathman, A., Gleicher, F., Boninger, D. S., \& Edwards, C. S. (1994). The consideration of future consequences: weighing immediate and distant outcomes of behavior. Journal of Personality and Social Psychology, 66(4), 742-752.

Sunstein, C. R., \& Thaler, R. H. (2003). Libertarian paternalism is not an oxymoron. The University of Chicago Law Review, 70(4), 1159-1202.

Thaler, R. H. (1994). Psychology and savings policies. The American Economic Review, 84(2), 186-192.

Thaler, R. H., \& Sunstein, C. R. (2008). Nudge: improving decisions about health, wealth and happiness (Kindle 2 version.). Retrieved from http://www.amazon.com

Thaler, R. H., Sunstein, C. R., \& Balz, J. P. (2010). Choice architecture. Retrieved from http://ssrn.com/paper=1583509

United States, Working Group on Retirement Plan Leakage. (1998). Report of the working group on retirement plan leakage. Retrieved from http://www.dol.gov/ebsa/publications/leaknew1.htm

Van Rooij, M. C. J., Lusardi, A., \& Alessie, R. J. M. (2011). Financial literacy and retirement planning in the Netherlands. Journal of Economic Psychology, 32(4), 593-608.

Van Rooij, M. C. J., Lusardi, A., \& Alessie, R. J. M. (2011). Financial literacy and stock market participation. Journal of Financial Economics, 101(2), 449-472.

Van Rooij, M. C. J., Lusardi, A., \& Alessie, R. J. M. (2012). Financial literacy, retirement planning and household wealth. The Economic Journal, 122(560), 449-478. 